DOI:10.24193/tras.SI2019.2

Published First Online: 2019/12/21

\section{EUROPEAN PHILANTHROPIC BEHAVIOR PATTERNS: CHARITABLE GIVING, NON-PROFIT AND WELFARE REGIMES IN THE EUROPEAN UNION}

\section{Adela LAZĂR \\ Adrian HATOS}

Abstract

The connection that links patterns of philanthropic behavior with the organization of state delivery of welfare and the development of civil society has been theorized recently. Off this line of thought we refer to the Esping-Andersen's well-known welfare regimes: Liberal, Conservative and Social-Democratic (1990), respectively, more recently, to the philanthropic regimes elaborated by Pennerstorfer and Neumeyr (2017): Liberal, Social-Democratic, Corporatist, Mediterranean and Eastern European regimes. In order to test the taxonomy of the non-profit regimes developed by the aforementioned authors, we employed the more recent data of the 201074.1 Eurobarometer. In our approach we classified the 29 countries and territories using the hierarchical clustering technique and identified three main classes of countries, named by us, regimes of philanthropic practices: Regime 1 (Great Givers), Regime 2 (Direct Givers) and Regime 3 (NGO Donors and Volunteers). A comparison of our classification with the one proposed by Pennerstorfer and Neumeyr shows similarities as well as the limits of the original taxonomy which can be partly overcome due to the larger and more variate pool of cases. Interpretations of the results in comparison with Esping's welfare regimes or to the alternative models of Crowding-out and Crowding-in of NGOs by state are also provided.

Keywords: welfare regimes, philanthropy, charity, non-profit regimes, philanthropic behavior.
Adela LAZĂR

PHD student, Doctoral School of Sociology, University of Oradea, Oradea, Romania

E-mail: adela.lazar11@gmail.com

\section{Adrian HATOS}

Professor, Department of Sociology and Social Work, Head of Doctoral School of Sociology, University of Oradea, Oradea, Romania

E-mail: ahatos@gmail.com 


\section{Introduction}

In a time of worldwide increase in social inequality, there is a raising interest in the ways in which welfare can be delivered through social innovation, including entrepreneurial solutions that combine philanthropy and the activity of the non-for-profit sector (Maclean, Harvey and Gordon, 2013). Non-for-profit organizations can be vehicles through which the philanthropic dispositions could be put to work in socially innovative ways in order to fight social exclusion and poverty. Such initiatives should take into consideration however the cross-cultural diversity of philanthropic modes and attitudes that have been already described and theorized by Pennerstorfer and Neumeyr (2017), and could impact the effectiveness of diffusion of social innovation across various cultural milieus.

Therefore, the article aims to bring light into understanding the differences in how people respond to the needs of other individuals through charitable giving by employing an international comparative approach. Understanding the philanthropic behavior lacks in great degree a contextual analysis and comparative approach of societies according to the typology of the philanthropic behaviors. Although the regional approach is often used in understanding human behavior, it is somewhat surprising that philanthropy is poorly represented in the literature from a comparative perspective (Schneider, 1996). Comparative information on philanthropic behavior in a global context is essential to correctly understand the causes behind these behaviors and the differences between them. On the one hand, this information is of real use to humanitarian fundraisers in choosing the right techniques and programs according to the philanthropic character of a country (Schneider, 1996). On the other hand, data on the degree of involvement in everything that a civic society implies provides us with valuable information on the values of a country, on the promoted and accepted behaviors, on the relationships among individuals, as well as on other latent issues such as trust, aspects of cultural, economic or political history (Casey, 2016).

The aim of the present research is first to test the existing classification models of the EU countries for philanthropic behaviors, and to propose a classification that integrates recent empirical evidence with these classifications and other institutional and economic taxonomies. Secondly, our aim is to assess these taxonomies with regard to current theories of state vs non-profit sector relationships.

The present approach, although using a relatively simple methodology (the classification of the individual philanthropic behaviors based on Jaccard distances, and then the classification of the countries based on the similarity of the philanthropy models), is innovative as it performs an empirical classification of all EU countries and tests the validity of this classification in relation to other social and institutional taxonomies. The secondary analysis of the data provided by the Eurobarometer 74.1 (2010) provides a clearer picture of the similarities and differences existing at the level of the EU countries on the predominant types of philanthropic behaviors. Compared to the Pennerstorfer and Neumayr (2017) seminal article, our article is an improvement as it 
employs a more valid operationalization of philanthropic giving and a different methodology in building the country-level taxonomy.

\section{Philanthropy}

As an organized form of helping out our fellow human beings, philanthropy is probably global. It is found in the Jewish and Christian religious traditions, but it is also present at the aboriginal people in Canada, for example, as a prerequisite of group life in a society (Wiepking and Handy, 2015). According to the World Giving Index conducted by the Charity Aid Foundation (CAF) worldwide in 2017, nearly 1 in 3 individuals donate money (30\%), $21 \%$ volunteer, and half of the population help a stranger (Low, 2017). Given the fact that, globally, philanthropy and volunteering have become more and more present in the life of individuals in a society, the study of philanthropy has practically become a necessity.

A short and concise definition of philanthropy was given over thirty years ago by one of the most well-known scholars in the field. He defined philanthropy as voluntary actions performed for the public good (Payton, 1988; Payton and Moody, 2008). Payton, the founding director of the Center on Philanthropy at Indiana University, and one of the most dedicated and well-known authors in the field, said, 'philanthropy is essential to a free, open, democratic civil society' (Payton and Moody, 2008). Salamon, another established author in the field, proposes a more operational definition of philanthropy, namely 'the private giving of time or valuables (money, security, property) for public purposes' (Salamon et al., 1992), the main purpose being to help increase the quality of life of others (Van Til, 1990). Therefore, philanthropy means the gesture of contributing to the public good by voluntarily donating money, goods, time/actions, donations that can be made both by the individual and by organizations/ groups (Wiepking and Maas, 2009). Philanthropy can therefore be analyzed at the individual level, respectively at the level of organizations or society as a whole (Schuyt et al., 2010).

Philanthropy and charity are both institutionalized aspects of generosity, and are often used interchangeably, in practice being very difficult to determinate and delimitate them (Wright, 2001). Charity, originated in the sphere of religious obligations, refers to a short-term reaction, usually based on feelings, being the help given momentarily in response to a person's need, necessity or suffering. The primary purpose of charity is to eliminate or rather alleviate a person's current suffering, while the primary objective of philanthropy is a more strategic, long-lasting one, acting at the level of the cause of social problems as to improve the quality of human life (Bremner, 2017; Friedman and McGarvie, 2003).

\section{Non-profit organizations}

The concept of social infrastructure is correlated to the concept of philanthropy, and it is one of the organized forms by which individual charity is transformed through philanthropic activity (donations and volunteering) into concrete actions of support 
for the categories in need. Social infrastructure includes all philanthropic non-profit organizations and groups referred to in scientific and common language under terms such as: non-profit/non-governmental sector, volunteering, third power, independent sector, civil society (Salamon et al., 1999b; Salamon et al., 2017).

The Johns Hopkins University Comparative Nonprofit Sector Project (Salamon et al., 1999b), initially involving 22 countries, is the first systemic attempt to conceptualize the non-profit sector in countries around the world. According to the study, in 1995 the non-profit sector in the 22 countries involved accounted for an average of $4.6 \%$ of the gross domestic product (GDP). The authors continue with the idea that if the non-profit sector was considered a separate national economy, it would be the eighth largest economy in the world (Salamon et al., 1999b).

\section{Philanthropy. Conceptualization and measurement}

Researchers' interest in philanthropy is growing. One talks about a restructuring of philanthropy, considering that today's philanthropy, the so-called 'modern philanthropy', differs from 'the traditional philanthropy' for having extended its objectives to causes such as nature conservation and health, compared to the causes of traditional philanthropy - poverty, well-being and education (Schuyt et al., 2010). This evolution is clearly parallel to the increasing relevance of post-materialist ideologies and to the emergence of new social movements (Hanspeter et al., 2015; Inglehart, 2008).

Conceptual analyses of philanthropy identify several aspects. When an individual notices the need of another individual, or is asked to help, the individual may offer not to help at all, may offer token help, or may offer serious helping. This general classification of the helping behavior is described by Bendapudi et al. (1996), who believe that the decision to get involved depends on the cost-benefit analysis. On the other hand, the awareness of need as a real one, asking for help, reputation and self-image, the values of the individual, altruism and the awareness of help as effective are other mechanisms to explain the degree of involvement and help to those in need (Bekkers and Wiepking, 2007). Inspired by the theories of consumer behavior (Howard, 1969), Peloza and Hassay (2007) propose a taxonomy of charitable behaviors according to the degree of involvement. Thus, the authors divide the helping behaviors into two broad categories: behavior with increased levels of involvement, respectively with low levels of involvement. The first category includes civic behaviors (volunteering, recommendations/recruitment, gifts in kind), financial contributions (gifts) and charitable purchases (participation in charitable events, purchase of products sold for charitable purposes - services/raffle, charity campaigns).

Thus, when individuals decide to help, they can either offer help that involves minimal involvement - token help, or act with a high level of involvement - serious help.

In order to operationalize these forms of individual philanthropy, various scales are used in the studies undertaken. In this regard we recall Gordon's scale (1960, beside Schuyt, Bekkers and Smit, 2010), which assesses altruism, and which in various adjusted forms is also used today. 
Schuyt, Bekkers and Smit (2010) draw attention to the importance of the particularities of the society in which we study philanthropy. They consider that there should be a close link between the scales chosen to operationalize philanthropy and the society in which it appears. The Charity Aid Foundation (CAF) report - recognized for one of the most comprehensive studies on individual involvement for philanthropic purposes - presents probably one of the simplest scales but with a great power of generalization. The report starts from the premise that money donations, volunteering and help given to a stranger are the most widespread forms of philanthropy - the annual report analyzes the answers to the three questions in over $90 \%$ of the countries in the world (Low, 2018).

\section{Philanthropy around the world}

At both global and European levels, statistics differ from one country to another. Myanmar (South Asia) tops the CAF World Giving Index for four consecutive years (2013-2017) as the world's most generous country (Low, 2017) followed by Indonesia, Kenya, New Zealand, and the United States. It is estimated that over $€ 87$ billion is being annually donated in Europe (Hoolwerf and Schuyt, 2017). Motifs and beneficiaries vary significantly from one country to another. For example, in Holland, over $40 \%$ of donations go to religious organizations. In the UK about $27 \%$ of the donations go to health organizations, while in Norway $37 \%$ of total donations go to international charity, people preferring to help international causes (Hoolwerf and Schuyt, 2017).

According to Hoolwerf and Schuyt' s study (2017), there is no country that has a clear overview of all donations and forms of philanthropy, the analysis of philanthropic data is still in development, and the methods are not standardized yet; all these make the study of the philanthropic sector at the European level much harder, and the provided data is not a $100 \%$ match to reality.

The volume of these resources in the total revenue of non-governmental organizations can provide information on the incidence of philanthropic donations.

Johns Hopkins University Comparative Nonprofit Sector (Salamon et al., 1999a) describes the sources of income of the non-profit sector. As already mentioned, one of these sources is philanthropy. In the 32 countries surveyed, only $12 \%$ of the income comes from private donations (donations from individuals, corporations or foundations). It is also mentioned that if volunteering was the equivalent of the donations in time, the contribution of philanthropy to the revenue of the civil society would increase from $12 \%$ to $30 \%$.

According to the above data, including the study conducted by Salamon et al. (2003), there are significant differences between countries in terms of the forms and the intensity of the philanthropic activities, including the activity of the society of a country, observable at the level of funding, structure, role, etc., as well as the most common forms of individual philanthropy. These differences, to a considerable extent, reflect the country's cultural, social, political and economic history (Salamon et al., 2003). 


\subsection{Differences between countries in the forms and size of philanthropy}

By means of their researches, psychologists, sociologists, economists, marketing and NGO specialists, philosophers and biologists try to better understand the mechanisms behind philanthropic behaviors (Alesina and Dollar, 2000; Batson and Shaw, 1991; Bekkers and Wiepking, 2007; Brand and Carter, 1992; Chen, 2009; Collett and Morrissey, 2007; Dawkins, 1976; Hammond, 2014; Herzog and Price, 2016; Penner et al., 2005; Piff et al., 2010; Sargeant, 1999; Simpson and Willer, 2015; Wiepking and Bekkers, 2012; Wilhelm et al., 2008; Wyatt et al., 2013). The philanthropic behavior in the various models identified in the literature is influenced by individual characteristics, on the one hand, and by situational factors, on the other hand. For example, we know that gender, age, marital status and socio-economic status are just a few of the individual characteristics that shape philanthropic behavior, and that are analyzed in numerous studies (Bekkers and Wiepking, 2007; Wiepking and Bekkers, 2012). On the other hand, how often we are asked to help or how we are asked to help (for example, we are asked for money or time) are situational factors that influence how we respond to the need of the other (Liu and Aaker, 2008; Wiepking and Handy, 2015). Little is known about the context factors such as the influence of culture and values, context in which people live (Winterich and Zhang, 2014).

Predictably, most of these studies use modelling of philanthropic behavior at the individual level. Few studies analyze this aspect from the perspective of modelling this behavior through intercultural comparisons using contextual variables in the explanatory models (Hustinx et al., 2010; Pennerstorfer and Neumayr, 2017; Winterich and Zhang, 2014). On the other hand, most research on intercultural comparisons focuses on issues such as the size of the philanthropic sector, government support, impact on the labor market, or other similar issues, and avoids to systematically analyze the relationship between context features and individual behaviors (Bekkers, 2016; Pennerstorfer and Neumayr, 2017; Salamon and Anheier, 1998). If we want to understand in depth these great inter-cultural differences in philanthropy, it is important to consider these aspects. Why, for example, do people in the Netherlands choose to offer about $40 \%$ of their donations to international causes, while people in Italy only $4 \%$ (Pennerstorfer and Neumayr, 2017)?

Moreover, analyses of the non-profit sector or on philanthropy do not follow the model of recent studies on economic, social, education systems or on the labor market, which proposed several classifications of developed societies. Most classifications of the non-profit sector are summed up to one-dimensional quantitative assessments (Salamon and Anheier, 1998), such as the CAF World Giving Index (Low, 2018).

However, there are several inspiring works that directly or indirectly explain philanthropic behaviors by adopting a comparative approach that correlates the degree of development of the non-profit sector with the level of the state intervention in providing assistance to the people in need. 'Social origins of civil society: Explaining the non-profit sector cross-nationally' by Salamon and Anheier (1998) is one of these reference works. The authors of the theory suggest the approach of 'social origins' 
where the emphasis is on the link between the third sector and the social, political and economic sector. Salamon and Anheier were inspired by the earlier theorizations on the 'social origins' of fascism and democracy (Moore, 1966), and by Esping Andersen' s classification of the welfare regimes (1990) where the central idea is that explaining complex social phenomena requires the approach of complex relationships between social classes and social institutions, not a linear approach of a certain factor, such as education, industrialization, etc. The two authors define the international qualitative and quantitative differences in the development of the non-profit sector by classifying these national configurations into four philanthropic regimes: liberal, social democratic, corporatist and statist (see also Pennerstorfer and Neumayr, 2017).

Table 1 briefly presents the four philanthropic regimes, highlighting the countries representative of each regime, namely the authors' characteristics and explanations regarding the specifics of each.

Table 1: Social origin theory

\begin{tabular}{|c|c|c|}
\hline & $\begin{array}{l}\text { Representative } \\
\text { countries }\end{array}$ & Characteristics of the non-governmental sector and of the society \\
\hline $\begin{array}{l}\text { The liberal } \\
\text { regime }\end{array}$ & $\begin{array}{l}\text { - the USA } \\
\text { - the UK }\end{array}$ & $\begin{array}{l}\text { - the size of the non-governmental sector is relatively large; } \\
\text { - government financial support is relatively small; and } \\
\text { - a society with a strong urban middle class. }\end{array}$ \\
\hline $\begin{array}{l}\text { The social } \\
\text { democratic } \\
\text { regime }\end{array}$ & $\begin{array}{l}\text { - Sweden } \\
\text { - Italy }\end{array}$ & $\begin{array}{l}\text { - high government spending on social assistance, but with a relatively small non- } \\
\text { governmental sector (according to the number of employees in the sector); } \\
\text { - in Sweden - representative of this regime, the explanations come from the fact } \\
\text { that in the analyzed period the working-class parties dominated politically, forcing } \\
\text { the increase of the government financial support on social assistance; and } \\
\text { - in Italy, the tradition of strong state support of the social sector (and with little } \\
\text { space for an independent, non-profit sector) is related to the influence of the } \\
\text { church on the social institutions. }\end{array}$ \\
\hline $\begin{array}{l}\text { The corporatist } \\
\text { regime }\end{array}$ & $\begin{array}{l}\text { - Germany } \\
\text { - France }\end{array}$ & $\begin{array}{l}\text { - a relatively large non-governmental sector, with large government support; and } \\
\text { - in both situations, due to different historical reasons, the state was forced or } \\
\text { induced to involve and support non-profit organizations. }\end{array}$ \\
\hline $\begin{array}{l}\text { The statist } \\
\text { regime }\end{array}$ & - Japan & $\begin{array}{l}\text { - a poorly developed non-governmental sector with little government support; and } \\
\text { - a country with a strong state control throughout history and with no movements } \\
\text { of the urban middle class or of the working class, allowing the state to have } \\
\text { autonomous power and thus influencing the poor development of the non-profit } \\
\text { sector. }\end{array}$ \\
\hline
\end{tabular}

Source: Salamon and Anheier (1998)

In a recent study, Pennerstorfer and Neumayr (2017) apply Salamon and Anheier's classification (1998) to test the crowding-out hypothesis - the decline in private donations in countries where governments offer large financial support to the social sector and vice versa - using the data from the 23 countries included in the Eurobarometer 62.2 (2004). Pennerstorfer and Neumayr (2017) observed a great heterogeneity in the last regime - the statist regime, so they considered it appropriate to divide this regime into two other regimes. Thus, the statist regime was replaced by the Mediterranean regime and by the Eastern European regime. The Mediterranean regime is charac- 
terized by a special involvement of the family and of the informal sector in ensuring the well-being. The non-profit sector of these countries is quite small, often under development. The most active areas of the non-profit sector are education and social services, as well as individual contributions. The Eastern European regime includes post-communist countries where it is assumed that people were accustomed to the state being the one responsible for social welfare, so the non-profit sector is a small one, activating mainly in the cultural and recreational fields. Individual donations in Eastern European countries are quite small.

Considering that these theories correlate philanthropy regimes, on the one hand, with the state intervention either as a donor of resources or as a provider of social services, it is normal to expect these international comparative categories to correlate with Esping-Andersen's classification of the welfare regimes, especially since it was Esping-Andersen's theory which initially inspired Salamon and Anheier's classification of philanthropic regimes (Esping-Andersen, 1990; Pennerstorfer and Neumayr, 2017). The proponent of the theory starts from the assumption that the definitions of the welfare state encountered so far do not cover the sufficient understanding of the concept. It shares to some extent the common definition that the welfare state implies the state's responsibility to ensure minimum basic conditions for its citizens. Following a comprehensive study on this concept, Esping-Andersen concludes that there are differences between welfare states, and that these differences are not linearly distributed but grouped into regimes. The author distinguishes and characterizes three regimes: conservative, liberal and social-democratic (Esping-Andersen, 1990). The conservative regime is described by the author as a family-focused regime that is based on traditional values, and where the state offers support through social services only in areas where family and community fail. Countries like Germany, France and Italy are considered representative states for the conservative regime. By contrast, we could say, the Scandinavian countries belong to the so-called social-democratic regime, a regime where the state is the central point and is responsible for ensuring welfare by providing numerous social services. As far as the liberal regime is concerned, the private sector (private pensions, private insurance, etc.) is encouraged to support social services, the market being the central institution of providing these services. Countries such as the USA, Canada or Australia offer this type of support (Esping-Andersen, 1990; Pennerstorfer and Neumayr, 2016).

We are inductively testing these correlations in Table 2 which presents the concurrent classifications of the EU countries according to these two relevant theoretical points of view.

The table summarizing the two classifications presents inconsistencies due to the absence of data that do not allow a robust analysis based on a simultaneous examination of the two taxonomies. However, certain plausible links can be identified: the association between corporative philanthropic regimes and the conservative welfare regime, respectively, between the social democratic philanthropic regime and the homonymous welfare regime. Associations with the two value classes are more difficult to identify due to the relatively small number of countries with a predominance of the 
Table 2: Classification of the countries according to the theory of non-profit regimes and welfare state theory

\begin{tabular}{|c|c|c|}
\hline COUNTRY & $\begin{array}{c}\text { NON-PROFIT REGIMES } \\
\text { (Pennerstorfer and Neumayr, 2016) } \\
\text { data from } 2004\end{array}$ & $\begin{array}{c}\text { WELFARE REGIMES } \\
\text { (Esping-Andersen, 1990) } \\
\text { data from } 1999\end{array}$ \\
\hline France & Corporatist & Conservative \\
\hline Belgium & Corporatist & Conservative \\
\hline West Germany & Corporatist & Conservative \\
\hline Italy & Mediterranean & Conservative \\
\hline Luxembourg & Corporatist & - \\
\hline Ireland & Liberal & Liberal \\
\hline Spain & Mediterranean & Conservative \\
\hline Portugal & Mediterranean & Conservative \\
\hline Estonia & Eastern European & - \\
\hline Latvia & Eastern European & - \\
\hline Lithuania & Eastern European & - \\
\hline Poland & Eastern European & - \\
\hline Slovenia & Eastern European & - \\
\hline Cyprus & - & - \\
\hline Malta & - & - \\
\hline Bulgaria & - & - \\
\hline East Germany & Corporatist & Conservative \\
\hline Finland & Social Democratic & Social Democratic \\
\hline Holland & Social Democratic & Social Democratic \\
\hline Denmark & Social Democratic & Social Democratic \\
\hline Sweden & Social Democratic & Social Democratic \\
\hline Austria & Corporatist & Liberal \\
\hline Slovakia & Eastern European & - \\
\hline Great Britain & - & Liberal (United Kingdom) \\
\hline Northern Ireland & - & - \\
\hline The Czech Republic & Eastern European & - \\
\hline Greece & Mediterranean & - \\
\hline Romania & - & - \\
\hline Hungary & Eastern European & - \\
\hline
\end{tabular}

traditional and survival values, characteristic mainly to former communist countries from Central and Eastern Europe, that do not appear in the other two classifications.

The correlation indices between the above-mentioned classifications support the hypothesis of our study according to which there is an international homogeneity of the philanthropic practices within the groups of certain countries - called regimes of philanthropy by Pennerstorfer and Neumayr' s terminology (2017). The aim of our study is to identify and describe these groups, and to check whether this classification replicates the classification of states in the so-called philanthropic regimes described by Pennerstorfer and Neumayr (2017). We will further compare this taxonomy with that of welfare regimes by Esping-Andersen (1990) in order to assess the competing theories of interdependence vs. government (Kim and Kim, 2016) and crowding-out 
vs. crowding-in ( $\mathrm{Lu}$ and $\mathrm{Xu}, 2018$ ) failure in explaining the relationships of government welfare expenditure with non-profit sector development, and individual inclination to donate for charitable causes. The crowding-out theory refers to the negative influence that governments have on private donations by increasing government subsidies, thus emphasizing the existence of a negative correlation between government support and donations. By contrast, the crowding-in effect appears when there is a positive correlation between public sector and donations (Andreoni and Payne, 2011). The interdependence theory emphasizes the importance of the interdependence of all economic sectors, and the fact that the size and the development of a country's non-profit sector must be analyzed from the point of view of these interdependencies is correlated with the size of the public sector, whereas the theory of government failure implies exactly the opposite, namely the poor functioning of the public authorities stimulate the development of the non-profit sector (Kim and Kim, 2016).

In doing so we will have an improved approach to measuring inclination to make donations which in Pennerstorfer and Neumayr (2017) was limited to only two items (donations to 'a charity organization or social aid organization' and 'an international organization such as development aid organization or human rights organization') both referring to donations to civil-sector organizations (see p. 541), and thus ignoring other forms of philanthropy as direct donations in cash or in kind.

\section{Data. Methods}

As already stated, we wish to test the classification of philanthropic regimes provided by Pennerstorfer and Neumayr (2017), and to interpret theoretically cross-national variations in philanthropic behavior. Our hypothesis is that there is an international homogeneity of the philanthropic practices within the groups of certain countries, and we can classify the country according to this, and there is a correlation between these classifications and the classification of states in the so-called philanthropic regimes described by Pennerstorfer and Neumayr (2017).

The present study was conducted by analyzing the data provided by Flash.Eurobarometer $74.1(2010)^{1}$. Although this Eurobarometer is not very recent, it was chosen since it was the only survey containing information on philanthropic behavior that included data about all EU countries (including Romania and Bulgaria - countries that joined the EU later). The 2010 European survey had four major areas of interest: poverty and social exclusion, mobile phone use, financial and economic crisis and international trade. The survey included 29 states and territories from the European Union (Germany was investigated and presented separately - East and West Germany, for example). In total, we are talking about 26,635 respondents, each aged 15 and over. The questionnaire was translated into the language of the country and applied at respondents' home using the face-to-face method of completing.

1 In our analysis we used secondary data of the Eurobarometer 74.1. The whole documentation and data set of the Eurobarometer can be consulted at https://www.gesis.org/index.php?id=2804. 
The objectives of the study were to focus our analysis on the items from the question 'Do you ever help poor people by doing any of the following?' (QA34).

Possible answers, as they appear in the Eurobarometer questionnaire, were:

1. Giving money to charities or associations that help the poor;

2. Volunteering for charities or associations that help the poor;

3. Offering clothing to the poor;

4. Help poor people find and have access to shelter or other appropriate services/ institutions;

5. Offering money to the poor;

6. Buying newspapers or other things sold by poor people; and

7. Delivering food to the poor.

As stated above, the seven items cover both donations to organizations and direct donations to those in need allowing a more valid measurement of inclination to donate as compared to Pennerstorfer and Neumayr (2017). Describing the philanthropic regimes in countries based on adults' responses to the seven philanthropy items in the Eurobarometer was done in several steps.

In the first step we realized classifications of philanthropy items at the country level, using hierarchical clustering in four classes of items on the basis of Jaccard measure of distance computed from the dichotomous answers of the subjects. The Jaccard distance is a very common distance measure used in clustering methods measuring dissimilarity between binary data. We used Jaccard's measure of distance in our study to classify the combinations of answers (the seven items) specific to each country in clusters according to the similarity of the answers. The 30 classifications of items corresponding to each of the countries and territories included in the Eurobarometer corresponded to eight combinations: 16 countries with one combination, six countries with a second combination, two countries (Romania and Greece) in a third combination.

Table 3: Countries and their combinations of items in classes generated through multicriterial classification ${ }^{2}$

\begin{tabular}{cllllllll}
\hline Combination & \multicolumn{1}{c}{ Countries } & It.1 & It.2 & It.3 & It.4 & It.5 & It.6 & It.7 \\
\hline & $\begin{array}{l}\text { France, Belgium, West Germany, Italy, Luxembourg, } \\
\text { Ireland, Spain, Portugal, Cyprus, Estonia, Latvia, } \\
\text { Lithuania, Malta, Poland, Slovenia, Bulgaria }\end{array}$ & 1 & 2 & 1 & 3 & 1 & 4 & 1 \\
& Holland, Denmark, N. Ireland, Sweden, Austria, Slovakia & 1 & 2 & 1 & 3 & 1 & 1 & 4 \\
\hline 2 & UK & 1 & 2 & 1 & 3 & 4 & 1 & 4 \\
\hline 3 & Greece, Romania & 1 & 2 & 3 & 2 & 3 & 4 & 3 \\
\hline 4 & East Germany & 1 & 2 & 1 & 3 & 4 & 4 & 1 \\
\hline 5 & Finland & 1 & 2 & 1 & 3 & 1 & 4 & 3 \\
\hline 6 & Czech Republic & 1 & 2 & 1 & 2 & 3 & 1 & 4 \\
\hline 8 & Hungary & 1 & 2 & 3 & 4 & 3 & 3 & 3 \\
\hline
\end{tabular}

2 The numbers in the table identify classes of items generated using hierarchical clustering. For example, in all countries items 1 (Donating money ...) and 2 (Working as a volunteer ...) are distributed in the first two different classes. 
As five of the identified categories comprise only one country each, we ran a second classification of the eight models using the differences in initial combinations as measure of distance. Applying this logic, we identified three classes.

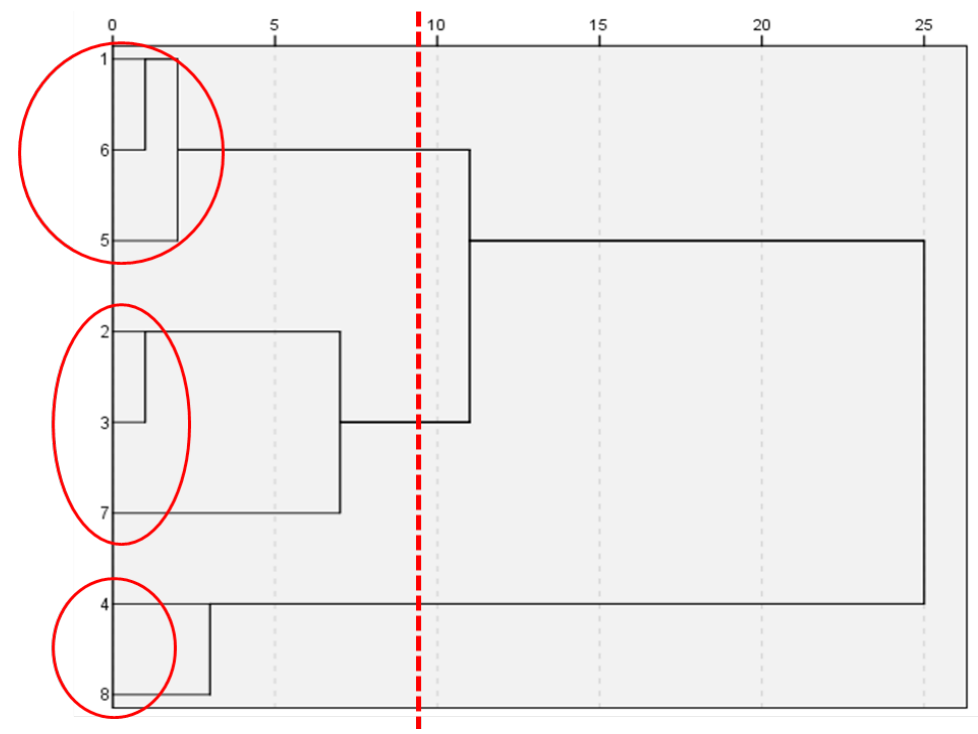

Figure 1: Dendrogram of classes of philanthropy patterns in the EU

The philanthropic specificity of the European Union countries can be described by three classes, that we chose to call, inspired by Esping-Andersen and Pennerstorfer and Neumayr regimes of philanthropic practices:

Regime 1: France, Belgium, West Germany, Italy, Luxembourg, Ireland, Spain, Portugal, Cyprus, Estonia, Latvia, Lithuania, Malta, Poland, Slovenia, Bulgaria, East Germany, Finland.

Regime 2: Holland, Denmark, Northern Ireland, Sweden, Austria, Slovakia, Great Britain, the Czech Republic.

Regime 3: Greece, Romania, Hungary.

In order to understand what lies behind the mere classifications we have cross-tabulated to the three resulted categories and the initial seven philanthropy items using the weighted data bases. The interpretation of the frequency distribution can be done using the chi-square adjusted residuals in order to avoid the effects of the discrepancies in the marginal distributions. Most interesting in understanding the distribution of philanthropic practices in the EU is the comparison of subjects Regime 1 and Regime 2, which comprise the largest share of the EU population (67.5\% and, respectively, $21.7 \%$ of the weighted sample).

While in terms of distance measures (see Figure 1) Regime 1 and 2 are closer to each other and separated through many differences from Regime 3, the comparison of philanthropic behavior patterns specific to each model shows a somewhat different story. The striking difference in behavior appears between Regime 2, on the one hand, 
Table 4: Chi-square adjusted residuals of the philanthropy classes and philanthropy items (pooled weighted data base)

\begin{tabular}{lccccccc}
\hline & $\begin{array}{c}\text { Give money } \\
\text { to charities }\end{array}$ & $\begin{array}{c}\text { Volunteer } \\
\text { in charities }\end{array}$ & $\begin{array}{c}\text { Giving } \\
\text { clothes }\end{array}$ & $\begin{array}{c}\text { Finding } \\
\text { shelters }\end{array}$ & $\begin{array}{c}\text { Give money } \\
\text { to people }\end{array}$ & $\begin{array}{c}\text { Buy papers } \\
\text { sold by }\end{array}$ & $\begin{array}{c}\text { Giving } \\
\text { food }\end{array}$ \\
\hline Regime 1 & $-16,3$ & 1,8 & 11,8 & 7,7 & 8,9 & $-22,5$ & 23,7 \\
Regime 2 & 32.2 & 3.9 & -7.7 & -7.5 & -15.7 & 26.9 & -33.2 \\
Regime 3 & $-21,8$ & $-8,8$ & -8 & $-1,5$ & 8,9 & $-3,3$ & 10,8 \\
\hline
\end{tabular}

and Regimes 1 and 3, on the other. One could say that Regime 2 is the regime of indirect donations and volunteering. The Nordic countries, well-known for the fact that the social services are strongly supported by the state (Esping-Andersen, 1990), have led to the development of several indirect philanthropic practices. Thus, citizens in countries in Regime 2 choose to help the needy in their country by means of NGOs. By contrast, Regime 1 and Regime 3 are characterized by the preference for direct donations, people in the countries included in this regime choose to directly help the needy with money, food or clothes.

People in countries in Regime 1 (Great Givers) are great givers with a clear preference for donations in kind - food, clothes or finding shelters, and direct donations in money to the needy ones, but less prone to give money to charities, buying papers sold by the poor while incidence of volunteering is at the EU population baseline. The people living in the three Eastern European countries belonging to Regime 3 (Direct Givers) - Greece, Hungary and Romania, appear to be also generous. However, their charitable practices of display show a clear preference for direct help - through money or food donations, and a rejection of donations to charitable organizations.

Unlike people in countries belonging to Regime 1 and Regime 3, subjects in countries in Regime 2 (NGO Donors and Volunteers) are more likely to help through monetary transfers by giving money to charities and buying papers sold by the needy ones, and being also the most likely to get involved in voluntary organizations. People in this category are less likely to help directly by direct cash or food donations. A significantly higher likelihood for the people from the countries classified in this category is to buy papers sold by the needy ones (while in the entire weighted sample they make up to $15.2 \%$, in this class they represent $25.8 \%$ ).

\section{Comparing the regimes}

The overlap of our classification with the ones in the literature is only partial. The analysis of the philanthropic Regime 1 proposed by us shows that, from the 18 states that form the regime, five belong to the non-profit regime called by Pennerstorfer and Neumayr the corporative regime (France, Belgium, East and West Germany, Luxembourg), five belong to the non-profit regime called Eastern European (Estonia, Latvia, Lithuania, Poland and Slovenia), three belong to the non-profit regime called the Mediterranean (Italy, Spain, Portugal). Ireland (the liberal regime) and Finland (the social democratic regime) are the two exceptions from this philanthropic regime, and 
three other countries (Cyprus, Malta, Bulgaria) are not included in the study of the non-profit regimes. Regarding the welfare regimes (Esping-Andersen, 1990), most of the countries included in the philanthropic regime proposed by us are conservative countries, with the exception of Ireland (liberal) and Finland (social democratic).

The most consistent overlap is in the case of our philanthropic Regime 2 (includes seven countries: Holland, Denmark, Sweden, Austria, Slovakia, Great Britain, Northern Ireland) that corresponds roughly in terms of country composition to the social-democratic regime proposed by Pennerstorfer and Neumayr (2017).

The philanthropic Regime 3 includes Romania, Greece and Hungary from the Eastern European non-profit regime, respectively the Mediterranean regime according to Pennerstorfer and Neumayr's classification.

Table 5: Comparative presentation of philanthropic, non-profit and welfare regimes

\begin{tabular}{|c|c|c|c|}
\hline $\begin{array}{l}\text { PHILANTHROPIC } \\
\text { REGIMES } \\
\text { (date 2010) }\end{array}$ & COUNTRY & $\begin{array}{l}\text { NON-PROFIT REGIMES } \\
\text { (Penerstorfer, date 2004) }\end{array}$ & $\begin{array}{l}\text { WELFARE REGIMES } \\
\text { (Esping, date 1999) }\end{array}$ \\
\hline \multirow{18}{*}{ I } & France & Corporatist & Conservative \\
\hline & Belgium & Corporatist & Conservative \\
\hline & West Germany & Corporatist & Conservative \\
\hline & Italy & Mediterranean & Conservative \\
\hline & Luxembourg & Corporatist & - \\
\hline & Ireland & Liberal & Liberal \\
\hline & Spain & Mediterranean & Conservative \\
\hline & Portugal & Mediterranean & Conservative \\
\hline & Estonia & Eastern European & - \\
\hline & Latvia & Eastern European & - \\
\hline & Lithuania & Eastern European & - \\
\hline & Poland & Eastern European & - \\
\hline & Slovenia & Eastern European & - \\
\hline & Cyprus & - & - \\
\hline & Malta & - & - \\
\hline & Bulgaria & - & - \\
\hline & East Germany & Corporatist & Conservative \\
\hline & Finland & Social Democratic & Social Democratic \\
\hline \multirow{8}{*}{ ॥ } & Holland & Social Democratic & Social Democratic \\
\hline & Denmark & Social Democratic & Social Democratic \\
\hline & Sweden & Social Democratic & Social Democratic \\
\hline & Austria & Corporatist & Liberal \\
\hline & Slovakia & Eastern European & - \\
\hline & Great Britain & - & Liberal (United Kingdom) \\
\hline & Northern Ireland & - & - \\
\hline & The Czech Republic & Eastern European & - \\
\hline \multirow{3}{*}{ III } & Greece & Mediterranean & - \\
\hline & Romania & - & - \\
\hline & Hungary & Eastern European & - \\
\hline
\end{tabular}


Regarding our hypothesis on overlapping the philanthropic regimes over the model of non-profit regimes proposed by Pennerstorfer and Neumayr (2017) since the p-value threshold associated with the Fischer's Exact test is 0.502 , one cannot say whether there is an association between the two types of classifications or not. Thus, the statistical analysis shows that our hypothesis on the overlap between the philanthropic regimes and the non-profit regimes is not supported.

This is an important result as our classification analysis performed in two steps does not support the multi-regime classification proposed by Pennerstorfer and Neumayr (2017) when considering groupings of individual philanthropic behavior. One cannot distinguish among the corporatist, Mediterranean, liberal or Eastern-European philanthropic regimes as the two Austrian researchers suggest that subjects from countries in all the above four regimes have similar patterns of philanthropic behavior. The only clear dissimilarity regards the behavior of subjects from countries classified in Pennerstorfer and Neumayr as social-democratic which fall in a separate class in our classification. We can say that our classification, based on comparing patterns of philanthropic behavior, gives more credit to the original classification of welfare regimes by Esping-Andersen (1990) when interpreting the habits of charitable giving of Europeans as all countries classified in the conservative class fall into our first class while social-democratic countries fall in the second model.

Reading the results from the two competing theories of crowding-out and crowding-in effects of state provision of welfare on charitable, on the one hand, and of government failure vs interdependence models, on the other hand (Kim and Kim, 2016; Lu and $\mathrm{Xu}, 2018$ ), our results support a mixed picture which needs further analyses due to incomplete data. In their research, Kim and Kim (2016) emphasized the importance of understanding the non-profit sector in terms of relationships between all economic sectors. According to the results of the study carried out by the above-mentioned authors, government policies and macro and microeconomic trends are the ones that have a strong influence on the development of the non-profit sector. On the other hand, the results of Lu and Xu's research (2018) show no strong link between government activity and non-profit sector. According to them, the government, through its activity, can at most facilitate the development efforts of the nonprofit sector. Thus, in countries classified by Esping-Andersen as conservative, with corporatist welfare, based on contributions and marketization of welfare provision, charitable giving tends to be direct to those in need. As such, it complements the welfare interventions of the state confirming the theory of government failure (Weisbrod, 1986). Moreover, this tends to be the case of the Mediterranean countries and in many of the Eastern-European former Communist countries. On the other hand, in the egalitarian and rich in welfare - based on heavy taxation - social-democratic countries the tendency is toward giving to charities (NGOs) which supports the crowding-in models, on the one hand, and an interdependence perspective of the state-civil-society correlation, on the other hand. In the case of these countries, a more detailed knowledge of the types of charities people are giving their resources to would help clarify if we face welfare 
complement or a reaction to international governance failure - if it turns out that most of the donations go to international charities.

It proves more difficult to interpret the patterns of philanthropic behavior in Regime 3, which includes two former communist countries from Eastern Europe (Hungary and Romania) and a Mediterranean one (Greece). We know that adults in these countries are least inclined to provide aid to charities, in either form, and that are similar to people in Regime 1 in their willingness to provide direct aid, especially in cash. Part of the story could be, with regard to the weak availability of donating through charities, the communist past in Hungary and Romania with its' legacy of statism and the subsequent underdevelopment of NGOs, on the one hand, and the size of the welfare activities implemented by the Orthodox churches in Greece and Romania, on the other hand. Moreover, the tendency of preference for direct cash donations might be explained in cultural terms for the two Orthodox countries with high levels of religiosity. However, these arguments are somehow contradicted by cases like Bulgaria - which is indeed less religious ${ }^{3}$ (Evans and Baronavski, 2018) than the other two mentioned, predominantly Orthodox countries - or former communist countries like Poland or Czech Republic which make the behavior of Hungarians seem odd.

\section{Conclusions}

In our article we investigated the correlation of patterns of philanthropic behavior in the 29 countries of the European Union with previous classifications of charitable giving and welfare state regimes looking for a deepening of understanding of the types of generous behavior. We took advantage of the seven items of philanthropic behavior included in the 2010 Eurobarometer which is, to our knowledge, the largest dataset of this sort that includes data collected from subjects from the countries that joined the EU later - Romania and Bulgaria.

In order to identify patterns of charitable giving, we applied a two-stage classification: in the first stage we classified the seven items in each country using hierarchical clustering, and in the second stage we classified the countries based on the combinations of variables obtained in the first stage using again hierarchical clustering.

The 29 countries and territories were consistently grouped into three classes philanthropic regimes whose composition overlaps largely with Esping-Andersen's classic classification of welfare regimes (1990), although this one contains a much smaller number of countries and, on the other hand, contradicts the nuanced classification of non-profit regimes proposed by Pennerstorfer and Neumayr (2017). The first and the largest category of countries (philanthropic regime), which includes roughly all the countries classified as conservative by Esping-Andersen, blends in corporatist, Mediterranean, Eastern-European and liberal countries from Pennerstorfer and

3 The Pew Research Center Report (Evans and Baronavski, 2018) can be read at https://www.pewre search.org/fact-tank/2018/12/05/how-do-european-countries-differ-in-religious-commitment/. 
Neumayr's classification. In all these countries one can record a preference for direct provision of charity, a tendency which is also visible in the third philanthropic regime (Romania, Greece and Hungary), which is different from the first group by the reluctance of provision of clothes and shelter.

Our classification tells also a nuanced theoretical story of state-non-profit sector development and individual inclination for philanthropic donations which suggests that both the government failure (Weisbrod, 1986) and interdependence theories of state-NGO welfare provision (Salamon and Anheier, 1998) are true, depending on the context and, moreover, the crowding-in hypothesis seems to apply across all contexts if we consider both direct and indirect giving (to the needy ones vs. to charities). Thus, in social-democratic welfare regime countries, people tend to donate heavily to charities and to avoid direct giving which supports the models of crowding-in and of interdependence. On the contrary, in the first class (the philanthropic regime) of our classification subjects prefer direct donations to the needy ones which comes probably as a response to the failure of government to deliver help to everyone who needs it. Our results suggest interesting interpretations considering the correlation of state and NGO development as the predominance of direct charities in conservative countries rejects the thesis of NGO sector development as a reaction to government failure. More precise theorization would require, however, a look into the kind of charities in the case of beneficiaries of donations in social democratic countries - are they international of delivering welfare locally and into the specific role of Church-based organizations in welfare delivery.

All the above theorizations have to be taken with several warnings which concern the limitations of the present research and the comparison with Pennerstorfer and Neumayr's research (2017). First, a valid test of crowding-out/crowding-in and government failure/interdependence hypotheses requires multilevel analysis relating data at the country-level about state and charity level welfare provision, NGO sector development also, which our article certainly does not cover. In addition, more robust explanations in terms of crowding-in and crowding-out should take into account not only the patterns of giving, as we have done in our research, but also the frequency of giving and the amounts of money donated data are neither recorded nor used by the present article.

\section{References:}

1. Alesina, A. and Dollar, D., 'Who Gives Foreign Aid to Whom and Why?', 2000, fournal of Economic Growth, vol. 5, no. 1, pp. 33-63.

2. Andreoni, J. and Payne, A.A., 'Is Crowding Out Due Entirely to Fundraising? Evidence from a Panel of Charities', 2011, fournal of Public Economics, vol. 95, no. 5-6, pp. 334-343.

3. Batson, C.D. and Shaw, L.L., 'Evidence for Altruism: Toward a Pluralism of Prosocial Motives', 1991, Psychological Inquiry, vol. 2, no. 2, pp. 107-122.

4. Bekkers, R., 'Regional Differences in Philanthropy', in Jung, T., Phillips, S.D. and Harrow, J., Routledge Companion to Philanthropy, 2016, New York: Routledge, pp. 124-138. 
5. Bekkers, R. and Wiepking, P., 'Understanding Philanthropy. A Review of 50 Years of Theories and Research', 2007, Default fournal, [Online] available at https:/www.rug.nl/re search/portal/files/2814285/BekkersR-Philantropy-2007.pdf, accessed on June 26, 2019.

6. Bendapudi, N., Singh, S.N. and Bendapudi, V., 'Enhancing Helping Behavior: An Integrative Framework for Promotion Planning', 1996, The fournal of Marketing, vol. 60, no. 3, pp. 33-49.

7. Brand, L.R. and Carter, R.L., 'Sociobiology: The Evolution Theory's Answer to Altruistic Behavior', 1992, Origins, vol. 19, pp. 54-71.

8. Bremner, R.H., Giving: Charity and Philanthropy in History, New York: Routledge, 2017.

9. Casey, J., 'Comparing Nonprofit Sectors around the World: What Do We Know and How Do We Know It?', 2016, The Journal of Nonprofit Education and Leadership, vol. 6, no. 3, pp. 187-223.

10. Chen, G., 'Does Meeting Standards Affect Charitable Giving? An Empirical Study of New York Metropolitan Area Charities', 2009, Nonprofit Management and Leadership, vol. 19, no. 3, pp. 349-365.

11. Collett, J.L. and Morrissey, C.A., 'The Social Psychology of Generosity: The State of Current Interdisciplinary Research', Report for the John Templeton Foundation Generosity Planning Project, vol. 15, 2007.

12. Dawkins, R., The Selfish Gene, New York: Oxford University Press, 1976.

13. Esping-Andersen, G., The Three Worlds of Welfare Capitalism, Princeton, NJ: Princeton University Press, 1990.

14. Evans, J. and Baronavski, C., 'How Do European Countries Differ in Religious Commitment? Use Our Interactive Map to Find Out', Pew Research Center, 2018, [Online] available at https://www.pewresearch.org/fact-tank/2018/12/05/how-do-european-countries-differin-religious-commitment/, accessed on April 12, 2019.

15. Friedman, L.J. and McGarvie, M.D., Charity, Philanthropy, and Civility in American History, Cambridge: Cambridge University Press, 2003.

16. Hammond, S.I., 'Children's Early Helping in Action: Piagetian Developmental Theory and Early Prosocial Behavior', 2014, Frontiers in Psychology, vol. 5, [Online] available at https:// www.frontiersin.org/articles/10.3389/fpsyg.2014.00759/full, accessed on April 12, 2019.

17. Hanspeter, K., Koopmans, R., Duyvendak, J.W. and Giugni, M.G., New Social Movements in Western Europe: A Comparative Analysis, New York: Routledge, 2015.

18. Herzog, P.S. and Price, H.E., American Generosity: Who Gives and Why, New York: Oxford University Press, 2016.

19. Hoolwerf, L. and Schuyt, T. (eds.), Giving in Europe: The State of Research on Giving in 20 European Countries, Amsterdam: Lenthe Publishers, 2017.

20. Howard, J.A. and Sheth, J.N., The Theory of Buyer Behavior, New York: John Wiley and Sons, 1969.

21. Hustinx, L., Handy, F., Cnaan, R.A., Brudney, J.L., Pessi, A.B. and Yamauchi, N., 'Social and Cultural Origins of Motivations to Volunteer: A Comparison of University Students in Six Countries', 2010, International Sociology, vol. 25, no. 3, pp. 349-382.

22. Inglehart, R.F., 'Changing Values among Western Publics from 1970 to 2006', 2008, West European Politics, vol. 31, no. 1-2, pp. 130-146.

23. Kim, Y.H. and Kim, S.E., 'Testing an Economic Model of Nonprofit Growth: Analyzing the Behaviors and Decisions of Nonprofit Organizations, Private Donors, and Governments', 
2016, VOLUNTAS: International Journal of Voluntary and Nonprofit Organizations, vol. 27, no. 6, pp. 2937-2961.

24. Liu, W. and Aaker, J., 'The Happiness of Giving: The Time-ask Effect', 2008, fournal of Consumer Research, vol. 35, no. 3, pp. 543-557.

25. Low, J., 'CAF World Giving Index: A Global View of Giving Trends', Charities Aid Foundation, 2017, [Online] available at https://www.cafonline.org/docs/default-source/ about-us-publications/cafworldgivingindex2017_2167a_web_210917.pdf, accessed on April $12,2019$.

26. Low, J., 'CAF World Giving Index 2018: A Global View of Giving Trends', Charities Aid Foundation, 2018, [Online] available at https://www.cafonline.org/docs/default-source/ab out-us-publications/caf_wgi2018_report_webnopw_2379a_261018.pdf, accessed on April 12, 2019.

27. Lu, J. and Xu, C., 'Complementary or Supplementary? The Relationship between Government Size and Nonprofit Sector Size', 2018, VOLUNTAS: International fournal of Voluntary and Nonprofit Organizations, vol. 29, no. 3, pp. 454-469.

28. Maclean, M., Harvey, C. and Gordon, J., 'Social Innovation, Social Entrepreneurship and the Practice of Contemporary Entrepreneurial Philanthropy', 2013, International Small Business fournal, vol. 31, no. 7, pp. 747-763.

29. Moore, B., Social Origins of Dictatorship and Democracy, Boston: Beacon Press, 1966.

30. Payton, R.L., Philanthropy: Voluntary Action for the Public Good, New York: American Council on Education, 1988.

31. Payton, R.L. and Moody, M.P., Understanding Philanthropy: Its Meaning and Mission, Bloomington: Indiana University Press, 2008.

32. Peloza, J. and Hassay, D.N., 'A Typology of Charity Support Behaviors: Toward a Holistic View of Helping', 2007, Journal of Nonprofit \& Public Sector Marketing, vol. 17, no. 1-2, pp. 135-151.

33. Penner, L.A., Dovidio, J.F., Piliavin, J.A. and Schroeder, D.A., 'Prosocial Behavior: Multilevel Perspectives', 2005, Annual Review of. Psychology, vol. 56, pp. 365-392.

34. Pennerstorfer, A. and Neumayr, M. 'Examining the Association of Welfare State Expenditure, Non-profit Regimes and Charitable Giving', 2017, VOLUNTAS: International fournal of Voluntary and Nonprofit Organizations, vol. 28, no. 2, pp. 532-555.

35. Piff, P.K., Kraus, M.W., Côté, S., Cheng, B.H. and Keltner, D., 'Having Less, Giving More: The Influence of Social Class on Prosocial Behavior', 2010, fournal of Personality and Social Psychology, vol. 99, no. 5, pp. 771-784.

36. Salamon, L.M. and Anheier, H.K., 'Social Origins of Civil Society: Explaining the Nonprofit Sector Cross-nationally', 1998, VOLUNTAS: International fournal of Voluntary and Nonprofit Organizations, vol. 9, no. 3, pp. 213-248.

37. Salamon, L.M., Anheier, H.K., List, R., Toepler, S., Sokolowski, S.W. and Associates, Global Civil Society: Dimensions of the Nonprofit Sector, vol. 1, Boston: USV, 1999a.

38. Salamon, L.M., Anheier, H.K., List, R., Toepler, S., Wojciech, S.S., and Associates, Global Civil Society: Dimensions of the Nonprofit Sector, vol. 2, Baltimore: Center for Civic Society Studies, 1999b.

39. Salamon, L.M., Sokolowski, S.W. and List, R., Global Civil Society: An Overview, Johns Hopkins Comparative Nonprofit Sector Project, Center for Civil Society Studies, 2003. 
40. Salamon, L.M., Sokolowski, S.W. and Sturza, D., America's Nonprofit Sector: A Primer, New York: Foundation Center New York, 1992.

41. Salamon, L.M., Wojciech, S.S. and Haddock, A.M., Explaining Civil Society Development: A Social Origins Approach, Baltimore: Johns Hopkins University Press, 2017.

42. Sargeant, A., 'Charitable Giving: Towards a Model of Donor Behaviour', 1999, fournal of Marketing Management, vol. 15, no. 4, pp. 215-238.

43. Schneider, J.C., 'Philanthropic Styles in the United States: Toward a Theory of Regional Differences', 1996, Nonprofit and Voluntary Sector Quarterly, vol. 25, no. 2, pp. 190-210.

44. Schuyt, T.N., Bekkers, R. and Smit, J., 'The Philanthropy Scale: A Sociological Perspective in Measuring New Forms of Pro Social Behaviour', 2010, Social Work \& Society, vol. 8, no. 1, pp. 121-135.

45. Simpson, B. and Willer, R., 'Beyond Altruism: Sociological Foundations of Cooperation and Prosocial Behavior', 2015, Annual Review of Sociology, vol. 41, pp. 43-63.

46. Van Til, J., Critical Issues in American Philanthropy: Strengthening Theory and Practice, San Francsico: Jossey-Bass, 1990.

47. Weisbrod, B.A., Toward a Theory of the Voluntary Nonprofit Sector in a Three-sector Economy, Oxford: Oxford University Press, 1986.

48. Wiepking, P. and Bekkers, R., 'Who Gives? A Literature Review of Predictors of Charitable Giving. Part Two: Gender, Family Composition and Income', 2012, Voluntary Sector Review, vol. 3, no. 2, pp. 217-245.

49. Wiepking, P. and Handy, F. (eds.), The Palgrave Handbook of Global Philanthropy, New York: Palgrave MacMillan, 2015.

50. Wiepking, P. and Maas, I., 'Resources that Make You Generous: Effects of Social and Human Resources on Charitable Giving', 2009, Social Forces, vol. 87, no. 4, pp. 1973-1995.

51. Wilhelm, M.O., Brown, E., Rooney, P.M. and Steinberg, R., 'The Intergenerational Transmission of Generosity', 2008, Journal of Public Economics, vol. 92, no. 10-11, pp. 2146-2156.

52. Winterich, K.P. and Zhang, Y., 'Accepting Inequality Deters Responsibility: How Power Distance Decreases Charitable Behavior', 2014, Journal of Consumer Research, vol. 41, no. 2, pp. 274-293.

53. Wright, K., 'Generosity vs. Altruism: Philanthropy and Charity in the United States and United Kingdom', 2001, VOLUNTAS: International fournal of Voluntary and Nonprofit Organizations, vol. 12, no. 4, pp. 399-416.

54. Wyatt, G., West, S. and Gardner, A., 'Can Natural Selection Favour Altruism between Species?', 2013, Journal of Evolutionary Biology, vol. 26, pp.1854-1865. 